\title{
Vegetative response to burning on Wyoming mountain-shrub big game ranges
}

\author{
JOHN G. COOK, TERRY J. HERSHEY, AND LARRY L. IRWIN
}

\begin{abstract}
At the time of this research, Cook was research assistant and Irwin was associate professor, Dept. of Zoology and Physiology, University of Wyoming, Laramie 82071, and Hershey was district wildlife biologist, U.S. Forest Service, Medicine Bow National Forest, Encampment, Wyo. 82325. Cook is currently wildlife scientist and Irwin is national wildlife program manager, National Council of the Paper Industry for Air and Stream Improvement, Inc., P.O. Box 458, Corvallis, Ore. 97339, and Hershey is forest biologist, U.S. Forest Service, Fremont National Forest, 524 North G St., Lakeview, Ore. 97630.
\end{abstract}

\section{ABSTRACT}

Information on vegetative productivity and nutritive responses to burning in mesic, high elevation big sagebrush (Artemisia tridentata Nutt.) communities is limited. We investigated the effects of 2 wildfires and 3 prescribed fires on current year's production of herbs and selected shrubs for 3 years post-burn, and forage quality for 2 years post-burn in high elevation big sagebrush habitats in southcentral Wyoming. Production of perennial herbs on burned sites averaged twice that on controls, while production of annual herbs varied little 2-3 years post-burn. Burn-induced mortality of Saskatoon serviceberry (Amelanchier alnifolia (Nutt.) Nutt. ex Roem.) was $\leq 15 \%$, but a 6-fold increase in twig production more than compensated for plant losses. Mortality of true mountain mahogany (Cercocarpus montanus Raf.) and antelope bitterbrush (Purshia tridentata (Pursh) DC) averaged 25\% and $55 \%$, respectively, but these losses generally were compensated by increases in browse production. Crude protein content of herbs from late spring through early fall was significantly higher on burns for 2 years post-burn. These results suggest wellmanaged prescribed burning programs have potential to improve May through September diets of large herbivores in southcentral Wyoming mountain-shrub communities.

Key Words: browse production, burning, forage production, forage quality, nutrition, shrub survival.

Fire suppression in the northcentral Rocky Mountains during the last 75 years generally has favored the establishment of mountainshrub communities often dominated by old decadent shrubs (Roughton 1972) with considerable standing dead organic matter. Reduced accumulations of standing dead matter (Hobbs and Spowart 1984, Jourdonnais and Bedunah 1990), improved productivity of herbs and shrubs (Leege 1969, Peek et al. 1979, Wright 1985), and increased nutrient concentration (DeWitt and Derby 1955, Stransky

\footnotetext{
K. Baumchen, E. Amett, F. Blomquist, T. and C. Rinkes, and others assisted with data collection. Wyoming Game and Fish Department and U.S. Forest Service provided important logistical support. Funding was provided by the Wyoming Game and Fish Department, U.S. Forest Service, Foundation for North American Wild Sheep, Bureau of Land Management, Wyoming Outfitters and Guides Association, National Rifle Association, Boone and Crockett Club, and Rocky Mountain Bighom Society.The authors thank R. Riggs and N.T. Hobbs for helpful comments on earlier versions of this manuscript

Manuscript received 21 Dec. 1992.
}

and Halls 1978) can provide superior foraging conditions for wild ungulates after burning. But the results from studies of vegetative productivity and nutritive response to fire are highly variable (DeWitt and Derby 1955, Lay 1957, Launchbaugh 1964, Leege 1969, Stransky and Halls 1978, Merrill et al. 1980; 1982, Wood 1988, Uresk et al. 1980, Meneely and Schemnitz 1981, Demarchi and Lofts 1985, Jourdonnais and Bedunah 1990). Pre-burn vegetative composition, soil moisture and fertility, fire intensity, precipitation and grazing following burning. and other factors likely contribute to variations in vegetative response among studies (Wright 1985).

Both the effects of fire on vegetative productivity and nutrient content have not been reported as far as we are aware for mesic, high elevation $(\geq 2,300 \mathrm{~m})$ montane big sagebrush (Artemisia tridentata Nutt.) communities. The relatively unique environmental features of these communities, such as high precipitation (e.g., $>35 \mathrm{~cm}$ ), large fuel volumes, and high productivity likely preclude extrapolation of burn-response data more commonly collected from big sagebrush communities at lower elevations in the Great Basin. Thus, detailed assessments of the influence of fire on vegetation in these high elevation communities is warranted, and can assist the development of habitat management plans by range and wildlife managers.

We investigated the effects of 2 wildfires and 3 prescribed burns on productivity of herbs and selected shrubs, and nutrient values of herbs on high elevation montane big sagebrush ranges important to wild ungulates in southcentral Wyoming. Data were collected during the first 2-3 years after burning.

\section{METHODS}

\section{Study Areas}

We studied post-fire vegetative responses on 5 burned sites located within $30 \mathrm{~km}$ of Encampment, Wyo.: Douglas Creek, Encampment, Prospect Mountain, and the West Encampment 1988 and 1989 burns. The Encampment site was divided into 2 sampling units (Encampment NE and Encampment SW) based on differences in aspect (northeast vs. southwest) and vegetative communities. Site characteristics, burning dates, and weather at time of burning for each site are presented in Table 1. All sites except Encampment SW occurred on east-facing slopes and were dominated by mountain big sagebrush (Artemisia tridentata vaseyana Nutt.) and antelope bitterbrush (Purshia tridentata (Pursh) DC) prior to burning. Common graminoids included bluebunch wheatgrass (Agropyron spicatum (Pursh.) Scribn. \& Smith), king spikefescue (Leucopoa kingii (Wats.) 
Table 1. Site and preburn vegetative conditions, date, and weather during burning on 6 burned areas in southcentral Wyoming.

\begin{tabular}{|c|c|c|c|c|c|c|c|c|c|}
\hline \multirow[b]{2}{*}{ Bum } & \multirow[b]{2}{*}{ Type $^{1}$} & \multirow[b]{2}{*}{ Aspect } & \multirow[b]{2}{*}{ Elev } & \multirow{2}{*}{$\begin{array}{l}\text { Veg. } \\
\text { type }^{2}\end{array}$} & \multirow[b]{2}{*}{ Size } & \multirow[b]{2}{*}{ Date } & \multicolumn{3}{|c|}{ Weather } \\
\hline & & & & & & & Temp. & $\mathbf{R H}^{3}$ & Wind \\
\hline & & & $(\mathrm{m})$ & & (ha) & & (C) & $(\%)$ & (kph) \\
\hline Douglas Cr. & $\mathbf{W}$ & E-SE & 2,450 & MS/AB & 10 & $6 / 85$ & 26 & 24 & $16-20$ \\
\hline Encamp. NE & W & E-NE & 2,400 & MS/AB/SS & 100 & $9 / 85$ & 17 & 33 & $13-20$ \\
\hline Encamp. SW & W & SW & 2,350 & WS/TMM & 100 & 9/85 & 17 & 33 & $13-20$ \\
\hline Prospect Mtn. & $\mathbf{P}$ & E-SE & 2,380 & MS/AB/SS & 13 & 4/87 & 11 & 17 & $5-7$ \\
\hline West Enc. 1988 & $\mathbf{P}$ & E-SE & 2,400 & MS/AB & 41 & 4/88 & $\mathrm{na}^{4}$ & na & na \\
\hline West Enc. 1989 & $\mathbf{P}$ & E-SE & 2,400 & MS/AB & 31 & $4 / 89$ & na & na & na \\
\hline
\end{tabular}

$1 \mathrm{~W}=$ wildfire; $\mathrm{P}=$ prescribed fire.

2 Pre-burn vegetation community dominants: $M S=$ mountain big sagebrush;

WS = Wyoming big sagebrush; AB = antelope bituerbrush; SS = Saskatoon

serviceberry; TMM = tue mountain mahogany.

3 Relative humidity.

Weber), needle-and-thread (Stipa comata Trin. \& Rupr.), and Ross sedge (Carex rossii Boott). The Encampment SW site supported Wyoming big sagebrush (A. t. wyomingensis Nutt.) and true mountain mahogany (Cercocarpus montanus Raf.), with bluebunch wheatgrass and cheatgrass (Bromus tectorum L.) common in the understory. Plant names follow Dorn (1988).

Regional climate is semi-arid. Annual precipitation and temperature at Encampment average $38 \mathrm{~cm}$ and $5^{\circ} \mathrm{C}$, respectively (NOAA 1988). Average annual precipitation is probably greater on the study sites, because all were $150-250 \mathrm{~m}$ higher in elevation than the Encampment weather station. Aspen (Populus tremuloides Michx.) and lodgepole pine (Pinus contorta Dougl. ex Loud.) communities occurred in mosaics around the burned sites, indicating the high precipitation regime on the study sites. Soils are lithic, having developed from weathering of fine-grained igneous and metamorphic bedrock (Haas 1979). Burned sites are located within steep V-shaped canyons used seasonally by elk (Cervus elaphus) and pronghorn (Antilocapra americana), and yearlong by mule deer (Odocoileus hemionus) and Rocky Mountain bighorn sheep (Ovis canadensis). Cattle occupied these sites during summer but were excluded after burning except at Douglas Creek.

\section{Treatment and Response Variables}

The effects of fire on current annual production of herbs and shrubs was assessed at Douglas Creek, Encampment NE and SW, and Prospect Mountain. Data were collected on each burned site and an adjacent unburned control. Aspect, slope, and elevation of controls were similar to burned sites, and we assumed that vegetative differences between controls and burns were the result of fire (fire lines, snow drifts, and forest stringers in drainages prevented spread of fire from burned areas to controls).

We randomly selected sampling areas $(n=15$ at Prospect Mountain and Encampment NE and $n=10$ at Encampment SW and Douglas Creek) to estimate herb and shrub productivity. Herbivore exclosure cages were placed at each sampling area prior to the growing season. These cages, which measured $1.3 \times 1.3 \mathrm{~m}$, were too small to cover shrubs, so herbivores were excluded only from herbaceous plants. We assumed that herbivory on shrubs on burned and unburned sites were equal; subsequent field observations, however, suggested that herbivores preferred shrubs on burns vs. controls, so our estimates of shrub production on the burns likely were low. Cages were moved uphill $2 \mathrm{~m}$ after clipping each year to avoid sampling the same plants in successive years. We clipped the current year's herbaceous production at ground level in $1.2-\mathrm{m}^{2}$ circular plots in the exclosure cages. The harvested biomass was separated into 5 classes: bluebunch wheatgrass, other perennial grasses including sedges, annual grasses, perennial forbs, and annual forbs. We harvested all current year's twig growth from individual plants of serviceberry (Amelanchier alnifolia (Nutt.) Nutt. ex Roem.), bitterbrush, and true mountain mahogany. The 2 shrubs of each species nearest to the exclosure cage were sampled each year (data from each were averaged). No shrubs were reclipped among years. Herb and shrub samples were oven-dried at $65^{\circ} \mathrm{C}$ for 24 hours and weighed.

Densities of live and dead serviceberry, bitterbrush, and true mountain mahogany were estimated in permanent $1-\times 20-\mathrm{m}$ belt transects. Transects were located parallel to slope contours $5 \mathrm{~m}$ from each exclosure cage. In each transect, numbers of sprouting shrubs and fire-killed plants, identified by bark characteristics of burned stumps (Bunting et al. 1984), were counted, and survival rates were estimated by dividing the sum of sprouting plants by the number of sprouting and fire-killed plants. We did not monitor mortality of shrubs on the control areas, so fire's effect on shrub mortality may be slightly overestimated.

We calculated current annual twig production $\left(\mathrm{g} / \mathrm{m}^{2)}\right.$ on the burned sites by multiplying density of live shrubs by average twig production per plant. Twig production on the controls was calculated by multiplying total (live and dead) shrub density on the burns by average twig production per plant on the controls. These estimates of twig biomass per unit area are calculated projections rather than estimates directly derived from rigorous sampling.

Crude protein was estimated for herbs in 1986 and 1987 at Douglas Creek and in 1989 at the 2 West Encampment sites. In 1986 at Douglas Creek, we conducted protein analyses on the perennial herb samples (i.e., bluebunch wheatgrass, perennial grasses, and perennial forbs) collected in August for production estimates. In 1987 at Douglas Creek, samples of bluebunch wheatgrass, perennial grasses, and perennial forbs were collected in May, late July or early August, and early October from randomly-located plots on the burn and control sites. Twenty samples of each forage class were collected over the season. At the 2 West Encampment sites and control, herbaceous vegetation in $8,0.5-\mathrm{m}^{2}$ circular plots randomly-located on the control, 1 , and 2 year-old burned sites were clipped each month from late May through early November. All current-year's growth clipped in each plot was composited for nutritional analyses.

Samples used for nutritional assessments were oven-dried at $65^{\circ} \mathrm{C}$ for 24 hours and ground in a Wiley Mill to pass through a 1-mm sieve. Crude protein was estimated by a macro Kjeldahl technique (Horwitz 1980). Laboratory analyses were conducted by the Wyoming Dep. of Agriculture, Analytical Services Laboratory.

\section{Data Analysis}

Statistical differences in herb and shrub productivity between the 
burns and controls were identified with multivariate repeated measures ANOVA using the General Linear Models procedure of SAS (1985). Year and treatment (burned vs. control) were included as main effects. When F-statistics of either treatment or year $\mathbf{x}$ treatment interaction effects were significant, we used Duncan's New Multiple Range test to identify significant treatment effects within years.

Multivariate repeated measures analysis was used also to identify significant declines in live shrub density over time after burning. Year was included as the main effect. Orthogonal contrasts were used to identify differences between adjacent years when the year effect was significant.

Significant differences in crude protein content between samples collected from the control and burned sites during August 1986 at Douglas Creek were identified with t-tests. For samples collected in 1987 at Douglas Creek, simple linear regressions of protein and day of the year of sample collection were calculated for each within-treatment and within-forage class combination. Between-treatment differences in protein-calender day regression lines were determined with a test of homogeneity of slopes and intercepts using the General Linear Models Procedure of SAS (1985). The effect of burning on nutrient content at West Encampment also was evaluated using tests of homogeneity of slopes and intercepts, and Duncan's New Multiple Range test was used to identify significant differences between the control, 1 , and 2 year-old burn sites.

Statistical significance was established at $P \leq 0.05$ in all tests.

\section{Results}

\section{Herbaceous Response}

Total herbaceous current year's production averaged 2.2 times higher on the burns compared to controls, pooling data across all 4 sites. There was significant interaction between burning and year at Douglas Creek, Encampment NE, and Prospect Mountain, and the burn effect was significant at Encampment SW. The significant interaction at Douglas Creek and Encampment NE suggests burning depressed production the first year after fire, but significant increases occurred thereafter (Fig. 1). First-year depression in production was not apparent at Prospect Mountain and Encampment SW.

Production of bluebunch wheatgrass averaged 3.9 times higher on

\section{TOTAL HERBS

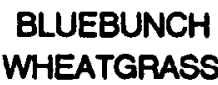

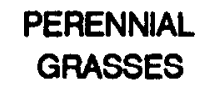

PERENNIAL FORBS
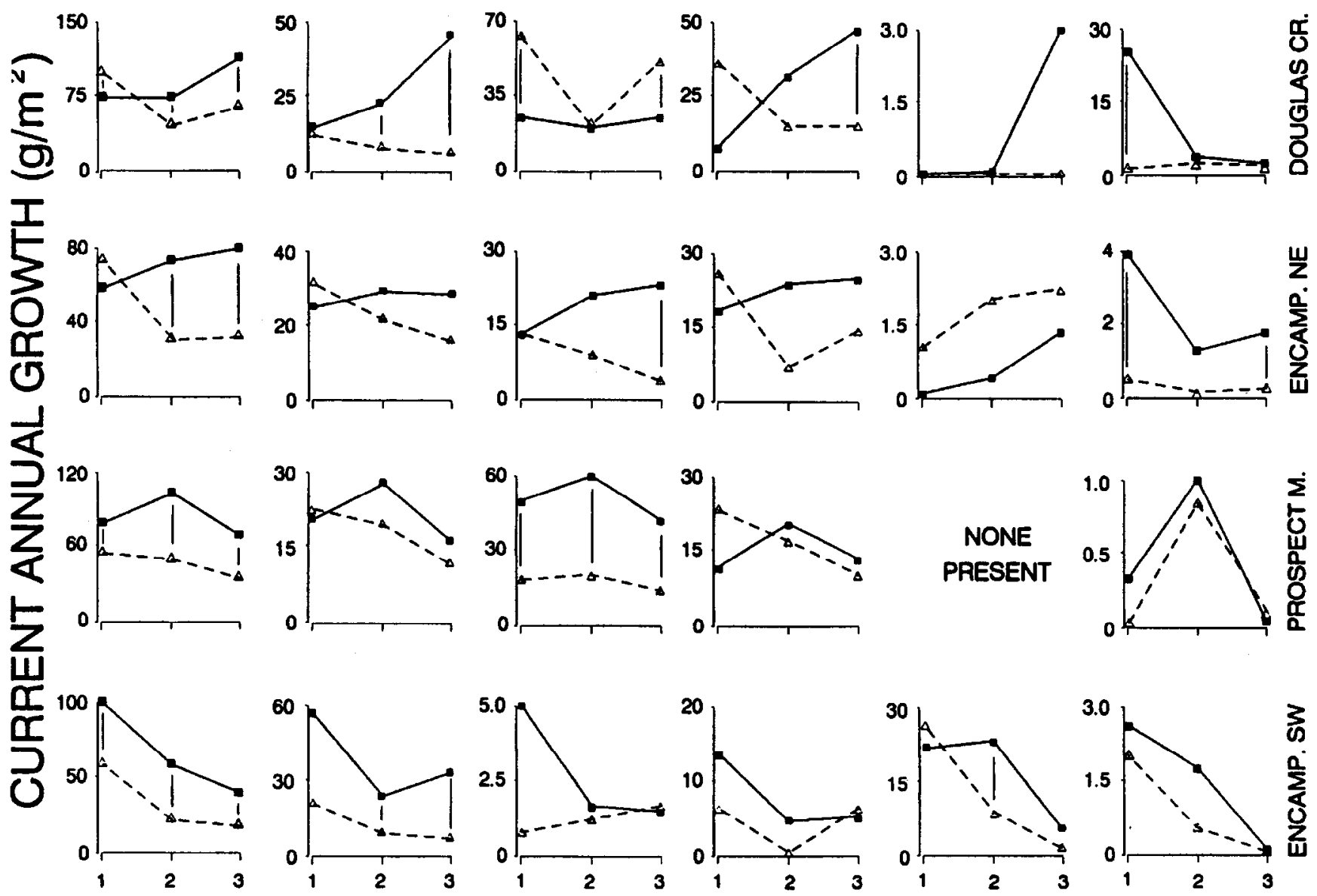

\section{YEARS AFTER BURNING}

Fig. 1. Current annual growth of all herbaceous vegetation, bluebunch wheatgrass, other perennial grasses, perennial forbs, annual grasses, and annual forbs on 4 burned (solid squares, solid lines) and unburned control sites (open triangles, dashed lines) in southcentral Wyoming. Vertical bars indicate significant differences $(P<0.05)$ between treatments in a given year. 
Table 2. Survival (\% of preburn abundance $\pm 95 \%$ confidence intervals) of serviceberry, bitterbrush, and true mountain mahogany after burning at Encampment and Prospect Mountain, 1986-89. All bitterbrush plants died after burning at Douglas Creek.

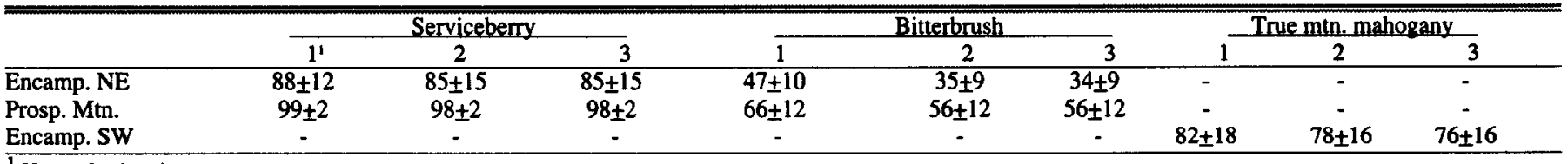

Years after burning.

burns by the third year, pooling data across all sites. The burn $\mathrm{x}$ year interaction was significant at Douglas Creek, and the burn effect was significant at Encampment SW. Significant increases in production of bluebunch wheatgrass did not occur until the second year after burning at both of these areas (Fig. 1). Burning did not have significant effects on bluebunch wheatgrass production at Encampment NE and Prospect Mountain.

The year $x$ burn interaction effect on production of other perennial grasses was significant at Douglas Creek and Encampment NE. At Encampment NE, 3 years were required for significant increases to occur, whereas at Douglas Creek, production of perennial grasses was significantly lower the first and third years post-burn (Fig. 1). Main effects of burning and year were significant at Prospect Mountain; production on this burn was higher each year of the study. Burning did not affect production of perennial grasses at Encampment SW.

Burning generally had insignificant effects on perennial forbs (Fig. 1). Neither burn nor year effects were significant for perennial forbs on any site, and the bum $x$ year interaction was significant only at Douglas Creek. Here, production of perennial forbs was significantly higher on the burn by the third year.

The effect of burning on production of annual herbs was generally insignificant particularly by the third year post-fire (Fig. 1). The burn $x$ year interaction for annual grasses was significant only at Encampment SW; significant increases occurred the second year post-burn. Burning did not significantly affect production of annual grasses at the other sites. The burn $x$ year interaction for annual forbs was significant at Douglas Creek, where production was elevated only the first year post-fire. Burning significantly increased production of annual forbs at Encampment NE the first and third years postfire (Fig. 1).

\section{Shrub Response}

Shrub survival varied among species and burns (Table 2). At Encampment NE, stems of bitterbrush declined significantly to $50 \%$ of preburn levels the first year after fire, declined significantly to $35 \%$ of preburn levels the second year after fire before mortality ceased. At Prospect Mountain, 66\% and 56\% of the bitterbrush plants survived through the first and second years, respectively, with significant declines occurring during the first 2 years. Fire eliminated bitterbrush at Douglas Creek. Serviceberry mortality was inconsequential at Prospect Mountain, but declined significantly to $88 \%$ of prebum levels the first year after fire. Eighteen and $22 \%$ of true mountain mahogany plants died by the first and second years post-fire, respectively, at Encampment SW.

The effects of burning on twig production of individual shrubs varied among species and burns as well (Fig. 2). The burn $x$ year interaction was significant for bitterbrush at Encampment NE and the burn and year effects were significant for this species at Prospect Mountain. Significant increases occurred only the third year and second year at Encampment NE and Prospect Mountain, respectively. The burn effect was significant for serviceberry twig production on both burned areas where it was present. Burning did not significantly affect twig production of true mountain mahogany (Fig. 2). Projections of twig production per unit area for these 3 species generally indicate increased productivity of shrubs compensated for reductions in live shrub densities (Fig. 2).

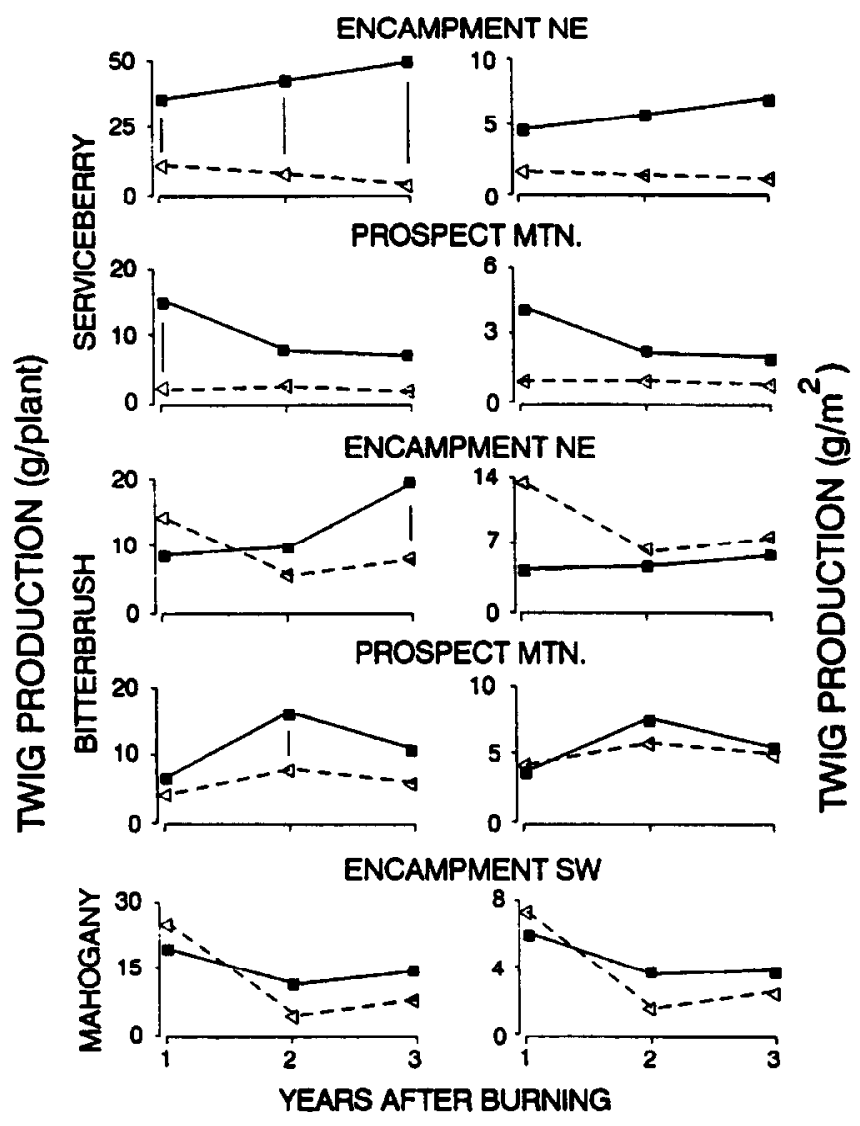

Burned $\rightarrow$ Unburned $-\rightarrow-$

Fig 2. Current annual production of serviceberry, bitterbrush, and true mountain mahogany twigs, expressed as g/plant and $\mathrm{g} / \mathrm{m} 2$, on 3 burned and unburned control sites in southcentral Wyoming. For graphs depicting g/plant, vertical bars indicate significant differences $(P<$ $0.05)$ between treatments within years.

\section{Forage Quality}

Burning significantly increased crude protein of herbs in all years and sites sampled. In August 1986 at Douglas Creek, protein averaged 30\% higher in herb samples collected from the burn (Fig. 3). In 1987 at Douglas Creek, protein content of the 3 herbaceous classes collected on the burn averaged as much as about $60 \%$ higher than on the control (Fig. 4). The rate of seasonal decline in protein content of perennial forbs and bluebunch wheatgrass collected from the Douglas Creek burn and control were similar, but differed signifi- 


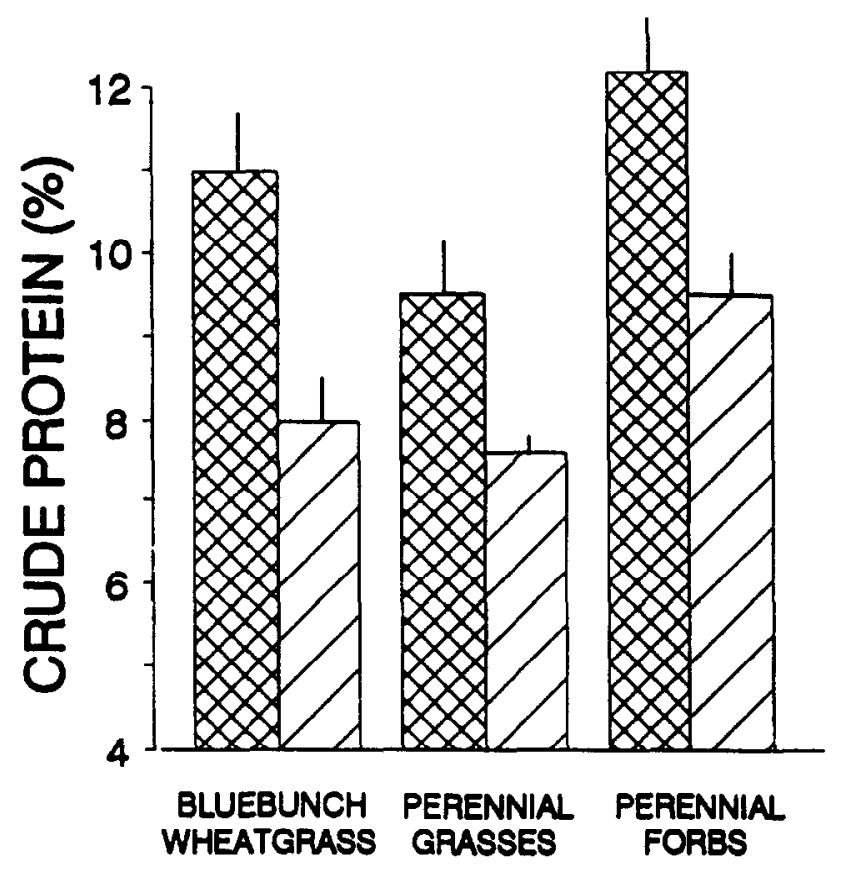

Burned $\triangle X X X$ Unburned $\square Z$

Fig 3. Crude protein of herbs collected during August 1986 on the Douglas Creek burn and control. Vertical bars denote SEM.

cantly for perennial grasses.

On the West Encampment sites, crude protein of herbs averaged $12.3 \%, 10.9 \%$, and $8.9 \%$ on the 1 year-old burn, 2 year-old burn, and controls, respectively, (Fig. 5). Forage quality was significantly higher on the 1 year-old burn than the 2 year-old burn, and was higher on both burns than on the control. The increase in forage quality in August coincided with above-normal precipitation (112\% of normal) that followed an April-July drought in which precipitation was $42 \%$ of normal (NOAA 1989).

\section{Discussion}

Burning increased productivity of perennial herbs by the second year post-burn, while generally inducing only short-term increases in annual herbs. With only 1 exception (perennial grasses at Douglas Creek), there was no significant reduction in production of any perennial herbaceous class on any burn after the first year post-burn. These positive responses occurred even on the June bum (Douglas Creek) and even though drought conditions prevailed during the sampling period (precipitation averaged $77 \%$ of normal from January 1986 through July 1989 [NOAA 1986-89]). The significant decrease in perennial grasses at Douglas Creek likely was due to the abundance of needle-and-thread and Ross sedge, 2 dense bunch-formers typically harmed by fire (Wright 1985). King spikefescue, a thizomatous species, and sandberg bluegrass (Poa secunda Presl.), both of which often respond well to burning (Wright 1985), comprised most of the perennial grass foliage on the other burns.

Such consistently positive responses in production contrast variously with findings of others. For example, Countryman and Cornelius (1957), Young and Evans (1978), and Merrill et al. (1980) reported increases in cheatgrass with concurrent decreases of peren-

\section{BLUEBUNCH WHEATGRASS}

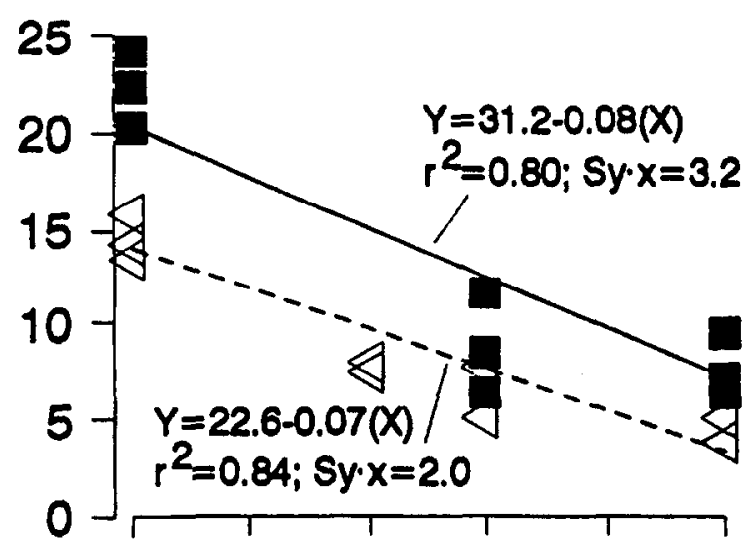

\section{PERENNIAL GRASSES}

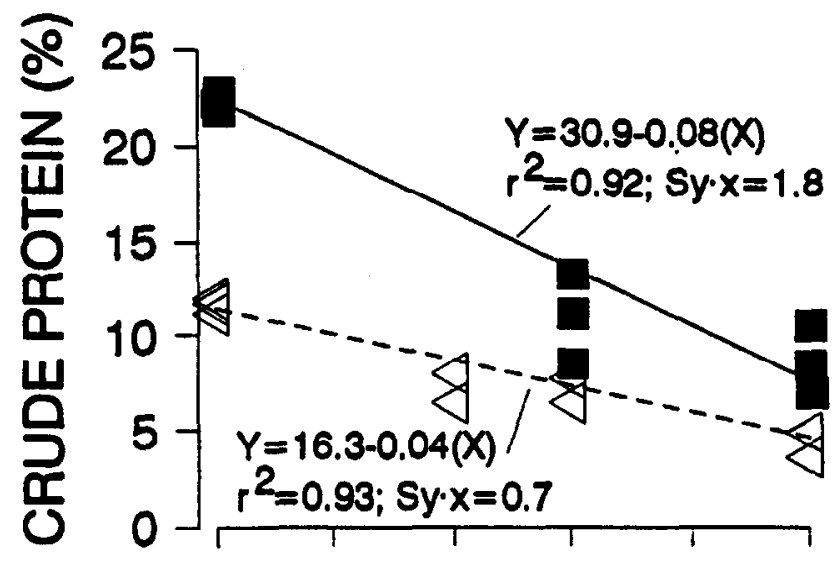

\section{PERENNIAL FORBS}

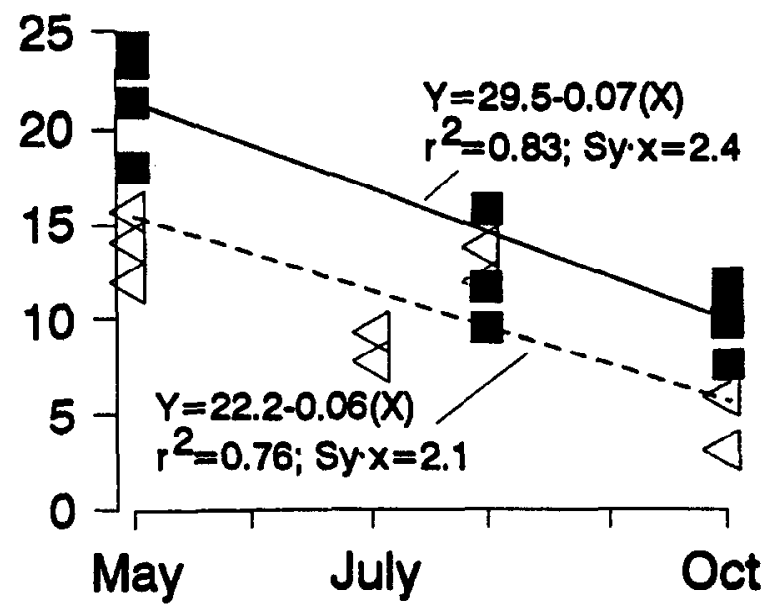

Fig. 4. Crude protein of herbs collected from May through October 1987 on the Douglas Creek burn (solid squares) and control (open triangles). 


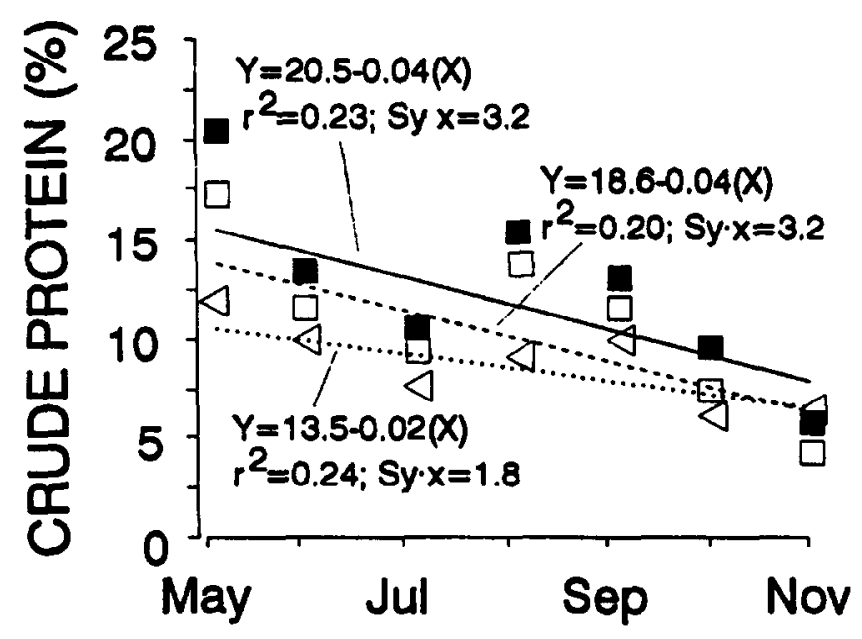

1989 burn - 1988 burn - $\boxminus-\cdot$ Unburned $\cdot \checkmark \cdots$

Fig. 5. Crude protein of forage collected from May through November 1989 on the West Encampment 1988 and 1989 burns and control. Each data point represents the mean of 8 samples collected each month. SE of each mean is $<1.0$.

nial herbs. Launchbaugh (1964), Towne and Owensby (1984), and Jourdonnais and Bedunah (1990) reported either post-fire declines or no changes in production of perennial herbs, with no significant increases in annuals. Engle and Bultsma (1984) and Towne and Owensby (1984) reported significant effects of season of burning. Bailey and Anderson (1978), Merrill et al. (1980), Uresk et al. (1980), and Wright (1985) reported variable responses among perennial herbaceous classes and species to burning.

Similarly, the substantial increases in crude protein of herbs after burning in all years and sites where examined contrast with the results of many other studies. Merrill et al. (1980), Meneely and Schemnitz (1981), Hobbs and Spowart (1984), Wood (1988), and Jourdonnais and Bedunah (1990) reported either minor or insignificant effects of burning on forage quality, and Lay (1957), Peek et al. (1979), Hobbs and Spowart (1984) contend that increases in forage quality, if they occur, are short-lived ( $\leq 2$ years).

We speculate that the consistent increases in plant productivity and nutrient concentration found in our study are a result of the mesic conditions and plant competitive characteristics that may be unique in high elevation big sagebrush communities. On burns occurring on easterly aspects, shrubs in the pre-burn plant communities were dense and total canopy cover was high (e.g., $2.5 \mathrm{shrubs} / \mathrm{m}^{2}$ and canopy cover of 60 to $70 \%$, J. Cook, unpubl. data). Burning removed $\geq 60 \%$ of shrubs, mostly big sagebrush, probably increasing the availability of soil water (Sturgis 1977), soil nutrients, and radiant energy flux to the surviving plants. These changes may account for increased nutrient content by facilitating earlier growth, increased rates of growth, and delayed senescence. Enhanced growth generally improves forage quality by increasing readily digestible cell solubles relative to cell wall constituents (Wilms et al. 1981, Minson 1990). An inverse relationship between forage quality and plant density in many ecosystems has been recognized (Daubenmire 1968, Hobbs and Swift 1985).

We postulate that high elevation plant communities with dense big sagebrush and without aggressive introduced annual herbs such as cheatgrass will respond well to prescribed burning. Reductions in shrub density and associated evapotranspiration losses (Sturgis 1977) should increase growth rates and extend the growing season, thereby enhancing vegetative productivity and quality. The length of time these enhancements persist will likely depend on rate of successional advance. In rangeland plant communities where (1) burning does not substantially alter plant composition, such as mountain grasslands, (2) burning results in rapid increases in competitive annual herbs, or (3) plant growth is restricted by severely limited precipitation, the effects of burning on vegetative productivity and nutrient content may be inconsistent and short-lived.

Serviceberry plants survived burning well, and increases in browse production more than compensated for decreases in plant density. Similar positive production responses of serviceberry have been reported by Leege (1969), Merrill et al. (1982), and Demarchi and Lofts (1985). Moderate losses (25\%) and insignificant increases in twig production of true mountain mahogany indicate few benefits of burning this species, at least in the short-term. Even so, our data demonstrate this species tolerates fire relatively well, and based on serviceberry and bitterbrush responses, we suspect losses could be reduced by spring-burning. We are unaware of other studies documenting the response of mountain mahogany to fire; more data is needed to reliably predict response and prescribe appropriate burning strategies for this species.

Survival of bitterbrush varied from $34-56 \%$, but increases in twig production generally compensated for reduced plant density. Survival on the spring burn ( $56 \%$ ) is similar to that reported by Blaisdell and Mueggler (1956), Bunting et al. (1984), Britton and Clark (1985) for the decumbant, multi-stemmed ecotype. Spring-burning appears most suitable for this species (Rice 1983, Britton and Clark 1985), perhaps because carbohydrate reserves in bitterbrush roots are high at this time (McConnell and Garrison 1966). Complete elimination of bitterbrush at Douglas Creek suggests summer burning is highly detrimental, as noted by others (Britton and Clark 1985).

Increased nutrient concentration, reduced structural and dead biomass, and increased productivity underscore the potential for burning to provide nutritional benefits to wild ungulates. Moreover, the relationships among diet quality, milk yields, and juvenile growth in wild ungulates (Peart 1968, Loudon et al. 1984), and summer weight gains in cattle (Skovlin 1962, Vavra 1983) identify the importance of dietary quality during summer. In our study, crude protein fell below requirements of a domestic ewe nursing a single lamb (National Research Council 1985) by early July on the controls, but generally exceeded requirements through early fall on the burns. Although large-scale removal of big sagebrush may reduce forage availability and dietary quality during winter, elimination of sagebrush from burned mosaics in mountain shrub communities should have little impact on ungulate diets during summer in southcentral Wyoming (Haas 1979, Cook 1990).

Managers who contemplate burning to improve habitats for ungulates should consider short- and long-term effects of fire on dietary and habitat needs of ungulates. Foliage of deciduous shrubs is an important component of ungulate diets during summer on mountainshrub ranges in southcentral Wyoming (Haas 1979, Cook 1990). We believe that repeated burning at frequent intervals (e.g., 5 years) likely will maintain high forage quality and herbaceous productivity for herbivores (Peek et al. 1979), but the long-term effects on deciduous shrubs in particular and ecosystem productivity in general are unknown. More information on shrub survival (Leege 1979, Martin and Driver 1983), seedling establishment (Martin and Driver 1983, Bunting et al. 1984), and soil fertility (Hobbs and Schimel 1984) is required to make informed management decisions on frequency of burning. If managers desire to enhance plant productivity and retain deciduous browse in burned habitats, we recommend creating a mosaic of different-aged burned and unburned habitats where a treat- 
ment unit is burned once every $15-25$ years.

Finally, our data suggest burning in spring minimizes damage to shrubs and perennial herbs and minimizes first-year increases in weedy annual species. Positive effects of spring burning reported here are consistent with findings of others in the Intermountain West (Smith and Busby 1981, Wright 1985, Britton and Clark 1985). But spring-burning may not be most suitable for all management objectives (Peek 1989). Greater plant mortality and exposure of mineral soil resulting from hotter burns in other seasons may enhance seedling establishment of deciduous shrubs (Martin and Driver 1983) and may prolong increases in forage quality. Effects of season of burning on community succession and forage quality and quantity needs further assessment as well.

\section{Literature Cited}

Bailey, A. W., and M. L. Anderson. 1978. Prescribed burning of a FestucaStipa grassland. J. Range Manage. 31:446-449.

Blaisdell, J. P., and W. F. Mueggler. 1956. Sprouting of bitterbrush (Purshia tridentata) following burning or top removal. Ecology 37:365-370.

Britton, C. M., and R. G. Clark. 1985. Effects of fire on sagebrush and bitterbrush. pp. 22-26 In: K. Sanders and J. Durham (eds.), Rangeland fire effects - a symposium. Bur. of Land Manage., Boise, Idaho. 124 pp.

Bunting, S. C., L. F. Neuenschwander, and G.E. Gruell. 1984. Fire ecology of bitterbrush in the Northern Rocky Mountains. Final report. Coll. For., Wildl., Range Sci., Univ. of Idaho, Moscow, Idaho. 26 pp.

Cook, J. G. 1990. Habitat, nutrition, and population ecology of two transplanted bighorn sheep populations in southcentral Wyoming. Ph.D. Diss., Univ. Wyoming, Laramie, Wyoming. $311 \mathrm{pp}$.

Countryman, D. M., and D. R. Cornelius. 1957. Some effects of fire on a perennial range type. J. Range Manage. 10:39-41.

Daubenmire, R. 1968. Ecology of fire in grasslands. pp. 206-266 In: J.B. Craig (ed.). Advances in ecological research, Vol. 5. Academic Press, N.Y., New York.

Demarchi, D. A., and S. Lofts. 1985. The effects of spring burning on the productivity and nutrient concentration of several shrub species in the southern Rocky Mountain Trench. MOE Tech. Rep. 19, B.C. Min. Envir., Victoria, B.C. $89 \mathrm{pp}$

DeWitt, J. B., and J. B. Derby, Jr. 1955. Changes in nutritive value of browse plants following forest fires. J. Wildl. Manage. 19:65-70.

Dorn, R. D. 1988. Vascular plants of Wyoming. Mountain West Publishing, Cheyenne, Wyoming. 340 pp.

Engle, D. M., and R. M. Bultsma. 1984. Burning of northern mixed prairie during drought. J. Range Manage. 37:398-401.

Haas, W. L. 1979. Ecology of an introduced herd of Rocky Mountain bighorn sheep in southcentral Wyoming. M.S. Thesis, Colorado State Univ., Fort Collins, Colorado. 343 pp.

Hobbs, N. T., and D. S. Schimel. 1984. Fire effects on nitrogen mineralization and fixation in mountain shrub and grassland communities. J. Range Manage. 37:402-405.

Hobbs, N. T., and R. A. Spowart. 1984. Effects of prescribed fire on nutrition of mountain sheep and mule deer during winter and spring. J. Wildl. Manage. 48:551-560.

Hobbs, N. T., and D. M. Swift. 1985. Estimates of habitat carrying capacity incorporating explicit nutritional constraints. J. Wildl. Manage. 49:814-822

Horwitz, W., editor. 1980. Official methods of analysis of the Association of Official Analytical Chemists. 13th Ed. Assoc. Off. Anal. Chem., Washington, D.C. 1018 pp.

Jourdonnais, C. S., and D. J. Bedunah. 1990. Prescribed fire and cattle grazing on an elk winter range in Montana. Wildl. Soc. Bull. 18:232-240.

Launchbaugh, J. L. 1964. Effects of early spring burning on yields of native vegetation. J. Range Manage. 17:5-6.

Lay, D. W. 1957. Browse quality and the effects of prescribed burning in southern pine forests. J. For. 55:342-347.

Leege, T. A. 1969. Burning seral brush ranges for big game in North Idaho. Trans. North Amer Wildl. Natur. Resour. Conf. 34:429-430.

Leege, T. A. 1979. Effects of repeated prescribed burns on northern Idaho elk browse. Northw. Sci. 53:107-113.

Loudon, A. S. I., A. D. Darroch, and J. A. Milne. 1984. The lactation performance of red deer on hill and improved species pastures. J. Agr. Sci., Camb. 102:149-158.

Martin, R. E., and C. H. Driver. 1983. Factors affecting antelope bitterbrush reestablishment following fire. pp. 256-265 In: A. R. Tiedemann and K. L. Johnson (compilers), Proc. research and management of bitterbrush and cliffrose in western North America. USDA For. Serv. Gen. Tech. Rep. INT-152. $279 \mathrm{pp}$.

McConnell, B. E., and G. A. Garrison. 1966. Seasonal variations of available carbohydrates in bitterbrush. J. Wildl. Manage. 30:168-172.

Meneely, S. C., and S. D. Schemnitz. 1981. Chemical composition and in vitro digestibility of deer browse three years after a wildfire. Southw. Natur. 26:365-374.

Merrill, E. H., H. F. Mayland, and J. M. Peek. 1980. Effect of a fall wildfire on herbaceous vegetation on xeric sites in the Selway-Bitteroot Wilderness, Idaho. J. Range Manage. 33:363-367.

Merrill, E. H., H. F. Mayland, and J. M. Peek. 1982. Shrub response after fire in an Idaho Ponderosa pine community. J. Wildl. Manage. 46:496-502.

Minson, D. J. 1990. Forage in ruminant nutrition. Academic Press, Inc., San Diego, California. 483 pp.

National Research Council. 1985. Nutrient requirements of sheep. Sixth revised edition. National Academy Press, Washington, D.C. 99 pp.

Neter, J., and W. Wasserman. 1974. Applied linear statistical models. R. D. Irwin, Inc., Homewood, Illinois. $842 \mathrm{pp}$.

NOAA. 1986-89. Climatological data - Wyoming. Asheville, NC.

Peart, J. N. 1968. Lactation studies with blackface ewes and their lambs. J. Agric. Sci., Camb. 70:87-94.

Peek, J. M. 1989. Another look at burning shrubs in northern Idaho. pp. 157. 159 In: D. M. Baumgartner, D. W. Breuer, B. A. Zamora, L. F. Neuenschwander, and R. H. Wakimoto (eds.), Prescribed fire in the Intermountain region, Symp. Proc. Washington State Univ., Pullman, Washington.

Peek, J. M., R. A. Riggs, and J. L. Lauer. 1979. Evaluation of fall burning on bighorn sheep winter range. J. Range Manage. 32:430-432.

Rice, C. L. 1983. A literature review of the fire relationships of antelope bitterbrush. pp. 256-265 In: A. R. Tiedemann and K. L. Johnson (compilers), Proc. research and management of bitterbrush and cliffrose in western North America. USDA For. Serv. Gen. Tech. Rep. INT-152. 279 pp.

Roughton, R. D. 1972. Shrub age structures on a mule deer winter range in Colorado. Ecology 53:615-625.

SAS Institute, Inc. 1985. SAS/STAT user's guide, release 6.03 edition. Cary, NC. 1028 pp.

Skovlin, J.M. 1962. Cow and calf weight trends on mountain summer range. USDA For. Serv. Res. Note PNW-220. 7 pp.

Smith, M. A., and F. Busby. 1981. Prescribed burning: effective control of sagebrush in Wyoming. Agr. Exp. Stn., RJ-165, Univ. Wyoming, Laramie, Wyoming. $12 \mathrm{pp}$.

Stransky, J. J., and L. K. Halls. 1978. Browse quality affected by pine site preparation in east Texas. Proc. Annu. Conf. Southeast. Assoc. Fish and Wildl. Agenc. 30:507-512.

Sturgis, D. L. 1977. Soil moisture response to spraying big sagebrush: a seven-year study and literature interpretation. USDA For. Serv. Res. Pap. RM-188. 12 pp.

Towne, G., and C. Owensby. 1984. Long-term effects of annual burning at different dates in ungrazed Kansas tallgrass prairie. J. Range Manage. 37:392-397.

Uresk, D. W., W. H. Richard, and J. F. Cline. 1980. Perennial grasses and their response to a wildfire in south-central Washington. J. Range Manage. 33:111-114.

Vavra, M. 1983. Managing grazing animal response to forestland vegetation. pp. 43-5l In: B. F. Roch, Jr. and D. M. Baumgartner (eds.). Proc. symp. on forestland grazing, Washington State Univ., Pullman, Washington.

Young, J. A., and R. A. Evans. 1978. Population dynamics after wildfires in sagebrush grasslands. J. Range Manage. 31:283-289.

Wilms, W. D., A. W. Bailey, A. McLean, and C. Kalnin. 1981. Effects of fall clipping or burning on the distribution of chemical constituents in bluebunch wheatgrass in spring. J. Range Manage. 34:267-269.

Wood, G. W. 1988. Effects of prescribed fire on deer forage and nutrients. Wildl. Soc. Bull. 16:180-186.

Wright, H. A. 1985. Effects of fire on grasses and forbs in sagebrush-grass communities. pp. 12-21 In: K. Sanders and J. Durham (eds.), Rangelands fire effects-a symp. Bur. of Land Manage,.Boise, Ida. $124 \mathrm{pp}$. 